\title{
Nitrogen balance study in young Nigerian adult males using four levels of protein intake
}

\author{
BY T. ATINMO ${ }^{1}$, C. M. F. MBOFUNG ${ }^{1}+\neq$, G. EGUN $N^{1 *}$ \\ AND B. OSOTIMEHIN ${ }^{2}$ \\ ${ }^{1}$ Department of Human Nutrition and ${ }^{2}$ Department of Pathology, College of Medicine, \\ University of Ibadan, Ibadan, Nigeria
}

(Received 22 March 1988 - Accepted 27 July 1988)

\begin{abstract}
1. The present study was carried out to estimate precisely, via the nitrogen balance technique, the protein requirement of Nigerians (earlier estimated via the obligatory $\mathbf{N}$ method) using graded levels of protein intake.

2. Fifteen medical students of the University of Ibadan who volunteered to participate in the study were given graded levels of protein $(0.3,0.45,0.6$ and $0.75 \mathrm{~g} / \mathrm{kg}$ body-weight per d) derived from foods similar to those usually consumed by the subjects.

3. Each subject was given each of the dietary protein levels for a period of $10 \mathrm{~d}$. Subjects were divided into two groups and the feeding pattern followed a criss-cross design with one group starting with the highest level of protein intake $(0.75 \mathrm{~g})$ and the second group starting with the lowest level of protein intake $(0.3 \mathrm{~g})$. Mean energy intake during each of the eleven experimental periods was maintained at $0.2 \mathrm{MJ} / \mathrm{kg}$ per d. After an initial $5 \mathrm{~d}$ adaptation period in each experimental period, $24 \mathrm{~h}$ urine and faecal samples were collected in marked containers for five consecutive days for $\mathbf{N}$ determination.

4. Mean $\mathrm{N}$ balance during consumption of the four protein levels $(0.30,0.45,0.6$ and $0.75 \mathrm{~g} / \mathrm{kg})$ were -11.02 (SD 8.07), -9.90 (SD 6.64), +9.70 (SD 4.15) and +5.13 (SD 4.62) respectively. Using regression analysis, the mean daily $\mathrm{N}$ requirement was estimated at $110.25 \mathrm{mg} \mathrm{N} / \mathrm{kg}$ body-weight $(0.69 \mathrm{~g}$ protein $/ \mathrm{kg}$ body-weight). Estimates of allowances for individual variations to cover $97.5 \%$ of the population adjusted this value to $0.75 \mathrm{~g}$ protein $/ \mathrm{kg}$ body-weight. Net protein utilization for the diet at maintenance level was estimated at 57.5 .
\end{abstract}

The available internationally accepted information on protein requirements is based on premises not related to the physical biological and social factors unique to the Nigerian environment. The frequently cited minimum physiological nutrient requirement (the amount that is consistent with optimal health and above which no further improvement in health occurs) is at best a statistical approximation and usually derived from studies of privileged healthy Caucasians living under protected conditions.

The often-quoted studies of Nicol \& Phillips (1976) in Nigeria suggested that there may be adaptive changes in protein requirements in chronically undernourished Nigerians. These studies, conducted in the late 1950 s, showed that Nigerian males were in positive nitrogen balance during short-term periods on a rice-protein intake of $0.44 \mathrm{~g} / \mathrm{kg}$ body-weight per d. Ever since the study by Nicol \& Phillips (1976) relatively few studies have been made in Nigeria in this interesting area of nutrient requirement, which for several reasons requires further examination. In a recent study by Atinmo et al. (1985), protein requirements of healthy Nigerian males were estimated, via the obligatory $\mathrm{N}$ loss method, to be $0.75 \mathrm{~g} / \mathrm{kg}$ per d. Compared with the recommended value of $0.57 \mathrm{~g} / \mathrm{kg}$ per d proposed by the Joint FAO/WHO ad hoc Expert Committee on Energy and Protein Requirements (World Health Organization, 1973) this level of requirement is quite high.

The obligatory $\mathbf{N}$ loss method of estimating protein requirement is, however, defective

Present addresses: * Department of Biochemistry, Lagos State University, Lagos, Nigeria.

$\dagger$ Department of Food Science and Nutrition, ENSIAAC, Ngaoundere University Centre, Ngaoundere, Cameroon.

$\ddagger$ For reprints. 
in that it assumes many factors. It has been demonstrated in healthy adults that $\mathrm{N}$ retention cannot be obtained by providing high quality protein at an $\mathrm{N}$ level that is equal to the summated total obligatory $\mathrm{N}$ losses (Calloway \& Merger, 1971; Young et al. 1973). Additional $\mathrm{N}$ is usually required. Thus the $\mathrm{N}$ balance technique of giving graded levels of protein has been suggested to be the most direct way of estimating protein needs. It involves the assessment of $\mathrm{N}$ balance responses to graded levels of protein intake, within the limits of submaintenance to maintenance $\mathrm{N}$ intake for adults or children over a range of intake levels that is close to those required for maintenance and normal growth (Garza, et al. 1977; Kishi et al. 1978; Oddoye \& Margen, 1979). This method, in principle, takes care of the effect of non-physiological conditions in the factorial method.

Considering the advantage of the $\mathrm{N}$ balance method, and above all the fact that protein requirements differ among similar individuals, just as food protein sources vary in their capacity to meet these protein requirements (Garza et al. 1977, Kishi et al. 1978), it was deemed necessary to define more precisely the protein requirements of Nigerians consuming ordinary local mixed foods under customary conditions of daily life. This was the main objective of the present study.

\section{MATERIALS AND METHOD}

\section{Subjects}

Fifteen healthy medical students of the University of Ibadan were recruited into the study. They were aged 19-21 years and weighted between 54 and $69 \mathrm{~kg}$ (average $60.75 \mathrm{~kg}$ ). Their health status was evaluated on the basis of medical history, physical examination and routine laboratory tests. The subjects were fully informed of the aim, nature and design of the experiment and they signed consent forms. They were studied under free-living conditions with close medical supervision. Daily body-weights were recorded at 07.00 hours throughout the entire study under standardized conditions (preprandial, postvoiding and with light indoor clothing). The subjects were engaged in their normal routine daily activities while maintaining a reasonable constant level of physical activity during the study period. The physical activities of the subjects were closely monitored by regularly checking a diary of daily activities which was kept by each subject.

\section{Diet and experimental design}

Diets were standardized, based on foods usually consumed by subjects (Table 1), and given in a meal pattern, three times daily at $07.00-08.00,13.00-14.00$ and $19.00-20.00$ hours. Complete vitamin and mineral supplements were added to ensure that no vitamins or minerals were limiting. The study lasted $54 \mathrm{~d}$ and consisted of four experimental diet periods, each of $10 \mathrm{~d}$ duration in which four different dietary protein levels were given $(0.30$, $0.45,0.60$ and $0.75 \mathrm{~g}$ protein $/ \mathrm{kg}$ per $\mathrm{d}$ ).

All the subjects were tested on the different levels of protein intake. To achieve this end, some of the subjects (subjects OS, AS, FA, KU, MA, OP, DU and HA) were assigned to an ascending sequence of dietary protein intake while the rest were assigned to a descending sequence. Their energy intake was carefully determined by the dietician based on a careful history of dietary habits, body-weight and evaluation of the physical activity of each of the subjects. This was fixed at a level of $0.2 \mathrm{MJ} / \mathrm{kg}$ body-weight per $\mathrm{d}$ throughout the experiment.

A protein-free diet was given on the 1st day before the beginning of each dietary period to promote rapid adaptation to the experimental diet. A $3 \mathrm{~d}$ break period with a free-choice diet separated each of the four experimental diet periods. During the experimental diet periods, the subjects were required to adhere to the experimental diet and thus eat only the food prepared by the dietician. 
Table 1. Composition of diet

\begin{tabular}{lc}
\hline & Amount provided $(\mathrm{g} / \mathrm{d})$ \\
\hline Cassava (Manihot esculenta) grated & 130 \\
Beef & 116 \\
Vegetables & 14 \\
Rice (cooked) & 400 \\
Bread & 120 \\
Refined sugar & 30 \\
Magarine & 30 \\
Tomatoes (fresh) & 80 \\
Palm oil & 40 \\
Onions & 40 \\
Peppers (dried) & 4 \\
Salt & Added to taste \\
Orange drink & Three bottles \\
Nutrient content & $45 \cdot 22$ \\
Protein (g) & 11.87 \\
Energy (MJ) & \\
\hline \hline
\end{tabular}

\section{Sampling and analysis}

Complete $24 \mathrm{~h}$ urine samples were collected daily thoughout the entire experimental period using hydrochloric acid as the preservative. Completenes of the urine collection was evaluated by analysing the urine for creatinine.

During each of the last $5 \mathrm{~d}$ of the $10 \mathrm{~d}$ period of each experimental diet, complete faecal samples were collected in individual containers, stored frozen and later combined and homogenized as a $5 \mathrm{~d}$ pooled sample for each subject. A carmine dye capsule was used as the faecal marker in each period. Food samples were collected in plastic bags, weighed, homogenized and portions taken and frozen.

$\mathrm{N}$ determination in food, urine and faecal samples was by a micro-Kjedahl method as modified by Munro \& Fleck (1969). Values obtained were evaluated statistically, including regression analysis and analysis of variance (ANOVA).

For the last $5 \mathrm{~d}$ of each $10 \mathrm{~d}$ experimental diet period, $\mathrm{N}$ balance was calculated from intake, and faecal, urine and miscellaneous losses (skin $\mathrm{N}$ loss was taken as $7.46 \mathrm{mg} \mathrm{N} / \mathrm{kg}$ body-weight per $\mathrm{d}$ from a previous determination (Atinmo et al. 1985)).

Estimates of individual $\mathrm{N}$ requirements was by linear regression equation relating $\mathrm{N}$ intake to balance (Rand et al. 1979). The protein intake at which $\mathrm{N}$ balance was at equilibrium was estimated as the $\mathrm{N}$ requirement. The biological value (BV) and the net protein utilization (NPU) of the diets were calculated by conventional methods. Obligatory urinary and faecal $\mathrm{N}$ losses were taken as 43.42 and $18.32 \mathrm{mg} \mathrm{N} / \mathrm{kg}$ respectively after Atinmo et al. (1985).

\section{RESULTS}

Table 2 shows the $\mathrm{N}$ excretion and balance of individual subjects. All subjects demonstrated increase in urinary $\mathbf{N}$ levels with increases in $\mathbf{N}$ intake. These changes were statistically significant $(P<0.05$; Table 3$)$. $\mathrm{N}$ balance became more positive with increasing $\mathrm{N}$ intake. The changes in individual apparent $\mathbf{N}$ balance for each of the subjects is as shown in Table 2 while the estimated true balance is summarized in Table 3. As a group, subjects showed negative $\mathrm{N}$ balance when on a daily protein intake level of 0.30 and $0.45 \mathrm{~g} / \mathrm{kg}$ body-weight per $d$. The degree of negative balance at each of these two levels of protein intake was significantly different when the order in which the protein was given was considered (Table 
Table 2. Nitrogen excretion and balance ( $\mathrm{mg} / \mathrm{kg}$ body-weight per $d$ ) in Nigerian college students

\begin{tabular}{|c|c|c|c|c|c|c|c|c|c|c|c|c|}
\hline \multirow{2}{*}{$\begin{array}{l}\mathrm{N} \text { intake... } \\
\text { Subject }\end{array}$} & \multicolumn{3}{|c|}{$55 \cdot 55$} & \multicolumn{3}{|c|}{$77 \cdot 42$} & \multicolumn{3}{|c|}{$100-36$} & \multicolumn{3}{|c|}{$130 \cdot 34$} \\
\hline & UN & FN & B & UN & FN & $\mathbf{B}$ & UN & FN & $\mathbf{B}$ & UN & FN & B \\
\hline OS & $48 \cdot 83$ & $25 \cdot 32$ & $-18 \cdot 19$ & $70 \cdot 13$ & $25 \cdot 12$ & $-15 \cdot 38$ & - & - & - & $106 \cdot 14$ & $26 \cdot 72$ & $+2 \cdot 26$ \\
\hline AS & $71 \cdot 16$ & 10.73 & $-27 \cdot 55$ & $71 \cdot 81$ & $23 \cdot 36$ & $-17 \cdot 19$ & $78 \cdot 39$ & $31 \cdot 34$ & +1.95 & $103 \cdot 42$ & $25 \cdot 97$ & +1.17 \\
\hline FA & 45.04 & 21.61 & -16.2 & 63.90 & 18.58 & -10.60 & 75.68 & 22.96 & +1.02 & - & - & - \\
\hline $\mathrm{KU}$ & 53.51 & 16.80 & -14.44 & 74.08 & 23.68 & -19.07 & 74.58 & 27.12 & +6.02 & 99.66 & 26.97 & +5.3 \\
\hline MA & 45.51 & 29.11 & -17.53 & 73.37 & 27.07 & -19.97 & 81.20 & 25.36 & +3.69 & 111.39 & 22.65 & +0.66 \\
\hline OP & 55.67 & 16.03 & -15.51 & 63.77 & 30.09 & -13.47 & 83.20 & 26.05 & +0.54 & 107.64 & 26.97 & -0.30 \\
\hline $\mathrm{DU}$ & 48.47 & 17.46 & -15.64 & 54.83 & 29.38 & -12.34 & 64.76 & 25.97 & +7.52 & 90.28 & 18.80 & +10.34 \\
\hline $\mathrm{HA}$ & 48.39 & 19.28 & -12.86 & 66.40 & 23.03 & -10.99 & 80.22 & 27.65 & +0.89 & 104.03 & 27.99 & +1.78 \\
\hline IW & 35.58 & 25.32 & -3.89 & 62.32 & 19.80 & -2.97 & 66.80 & 23.39 & +6.76 & 96.46 & 25.92 & +7.81 \\
\hline $\mathrm{EG}$ & 54.23 & 17.82 & -16.96 & 59.49 & 18.57 & -3.23 & 69.87 & 26.78 & -4.50 & 91.49 & 22.49 & +7.24 \\
\hline OM & 43.83 & 17.76 & -4.59 & 60.83 & 20.30 & -2.60 & 69.79 & 32.58 & -5.90 & 90.84 & 24.48 & +15.28 \\
\hline $\mathrm{OB}$ & 40.31 & 14.87 & -2.11 & 59.82 & 18.46 & -4.01 & 64.99 & 19.22 & +7.3 & 89.20 & 26.02 & +8.99 \\
\hline OR & 43.11 & 15.27 & -4.83 & 57.28 & 19.56 & -4.22 & 67.83 & 26.02 & -3.49 & - & - & - \\
\hline UD & 47.85 & 16.27 & -3.44 & 63.50 & 25.88 & -8.21 & 78.16 & 23.60 & -1.94 & 106.57 & 25.15 & +1.96 \\
\hline EK & 49.06 & 16.29 & -5.11 & 61.80 & 24.82 & -4.12 & 73.62 & 26.00 & +3.35 & 98.51 & 26.61 & +10.36 \\
\hline Mean & $48 \cdot 14$ & $18 \cdot 38$ & -11.02 & $65 \cdot 32$ & $23 \cdot 38$ & -9.90 & $72 \cdot 75$ & 25.89 & +1.97 & $100-09$ & $25 \cdot 38$ & $+5 \cdot 13$ \\
\hline SD & $8 \cdot 18$ & $4 \cdot 75$ & 8.07 & $6 \cdot 32$ & 3.86 & 6.64 & $6 \cdot 15$ & $3 \cdot 18$ & $4 \cdot 15$ & $7 \cdot 15$ & $2 \cdot 72$ & 4.62 \\
\hline
\end{tabular}

UN, urinary $N$; FN, faecal $N ; B, N$ balance.

Table 3. Daily nitrogen values ( $\mathrm{mg} / \mathrm{kg}$ body-weight per $\mathrm{d}$ ) with increasing $N$ intake in Nigerian college students

(Mean values and standard deviations for fifteen subjects)

\begin{tabular}{|c|c|c|c|c|c|c|c|c|c|}
\hline \multicolumn{2}{|c|}{ NI } & \multicolumn{2}{|c|}{ UN } & \multicolumn{2}{|c|}{ FN } & \multicolumn{2}{|c|}{ APP.NB } & \multicolumn{2}{|c|}{ EST.TNB } \\
\hline Mean & SD & Mean & SD & Mean & SD & Mean & SD & Mean & SD \\
\hline 55.55 & $2 \cdot 80$ & $48 \cdot 1$ & $8 \cdot 18$ & $18 \cdot 38$ & $4 \cdot 75$ & -11.02 & $8 \cdot 07$ & -18.48 & $8 \cdot 07$ \\
\hline $77 \cdot 42$ & 3.29 & $65 \cdot 32$ & 6.32 & $23 \cdot 38$ & 3.86 & -9.90 & $6 \cdot 64$ & $-17 \cdot 36$ & 6.67 \\
\hline $100-36$ & 6.76 & $72 \cdot 75$ & $6 \cdot 15$ & 25.89 & $3 \cdot 18$ & +1.97 & $4 \cdot 15$ & -5.49 & $4 \cdot 15$ \\
\hline $130 \cdot 34$ & 4.96 & 100.09 & $7 \cdot 15$ & $25 \cdot 38$ & 2.72 & $+5 \cdot 13$ & $4 \cdot 62$ & $-2 \cdot 33$ & $4 \cdot 62$ \\
\hline
\end{tabular}

NI, $\mathrm{N}$ intake; UN, urinary $\mathrm{N}$; FN, faecal N; APP.NB, apparent $\mathrm{N}$ balance (NI-UN-FN); EST.TNB, estimated true $N$ balance assuming $N$ losses from sweat as $7.46 \mathrm{mg} \mathrm{N} / \mathrm{kg}$ body-weight per d from previous estimates by Calloway \& Merger (1971).

Within vertical columns, mean values were significantly different from the other values (one-way ANOVA): $P<0.05$

4). On a protein intake of $0.60 \mathrm{~g} / \mathrm{kg}$ body-weight per $\mathrm{d}$, ten of the subjects achieved an apparent positive $\mathrm{N}$ balance and, when placed on a daily protein intake of $0.75 \mathrm{~g} / \mathrm{kg}$ bodyweight, all subjects except one were in positive $\mathrm{N}$ retention. The range of the $\mathrm{N}$ balance (excluding estimated losses through sweat) was $-0.30-15.8 \mathrm{mg} \mathrm{N} / \mathrm{kg}$ body-weight at the $0.75 \mathrm{~g} / \mathrm{kg}$ body-weight level of protein intake.

Estimated true balance (that includes estimated skin $\mathrm{N}$ loss of $7.46 \mathrm{mg} \mathrm{N} / \mathrm{kg}$ body weight per $\mathrm{d}$ ) resulted in a mean negative $\mathrm{N}$ balance of $-2.3 \mathrm{mg} \mathrm{N} / \mathrm{kg}$ per $\mathrm{d}$ even at the highprotein intake level of $0.75 \mathrm{~g}$ protein $/ \mathrm{kg}$ body-weight. 
Table 4. Nitrogen balance ( $\mathrm{mg} / \mathrm{kg}$ body-weight per d) according to order of protein intake (Mean values and standard deviations)

\begin{tabular}{|c|c|c|c|c|c|c|c|c|c|}
\hline \multirow{3}{*}{$\begin{array}{l}\mathrm{N} \text { intake }(\mathrm{mg} / \mathrm{kg} \text { body-wt per } \mathrm{d}) \ldots \\
\text { Order* }\end{array}$} & \multirow[b]{3}{*}{ Subjects } & \multicolumn{8}{|c|}{$\mathrm{N}$ balance $(\mathrm{mg} / \mathrm{kg}$ body-wt per $\mathrm{d})$} \\
\hline & & \multicolumn{2}{|c|}{55.5} & \multicolumn{2}{|c|}{77.42} & \multicolumn{2}{|c|}{$100 \cdot 36$} & \multicolumn{2}{|c|}{$130 \cdot 34$} \\
\hline & & Mean & SD & Mean & SD & Mean & SD & Mean & SD \\
\hline Ascending & OS-HA & $-17 \cdot 3$ & $4 \cdot 5$ & $-14 \cdot 9$ & 3.6 & $3 \cdot 1$ & 2.8 & 1.8 & 1.9 \\
\hline Descending & IW-EK & -5.9 & $5 \cdot 0$ & $-4 \cdot 2$ & 1.9 & -1.9 & $5 \cdot 0$ & 8.6 & $4 \cdot 3$ \\
\hline $\begin{array}{l}\text { Statistical } \\
\text { significance }(t \text { test }): P<\end{array}$ & -. & 0.00 & & 0.0 & & $\mathbf{N}$ & & 0. & \\
\hline
\end{tabular}

NS, Not significant.

* Order of intake of dietary protein, from 55.55 to 130.34 or from 130.34 to $55.55 \mathrm{mg} \mathrm{N} / \mathrm{kg}$ body-weight per d.

Table 5. Linear regresssion equations relating nitrogen balance $(\mathrm{Y})$ to $N$ intake $(\mathrm{X})$ for each of the Nigerian college students studied

\begin{tabular}{|c|c|c|}
\hline Subject & Regression equation & $\begin{array}{l}\text { Predicted mean intake to } \\
\text { achieve } \mathrm{N} \text { balance }\end{array}$ \\
\hline OS & $Y=0.27 X-34.85$ & 129.11 \\
\hline AS & $Y=0.42 X-49 \cdot 34$ & 117.47 \\
\hline FA & $Y=0.35 X-34.41$ & $98 \cdot 32$ \\
\hline KU & $Y=0.34 X-37.41$ & 110.02 \\
\hline MA & $Y=0.31 X-38.03$ & 122.69 \\
\hline OP & $Y=0.23 X-29.14$ & $126 \cdot 4$ \\
\hline DU & $Y=0.43 X-39.1$ & 90.93 \\
\hline HA & $Y=0.21 X-25.0$ & 118.96 \\
\hline IW & $Y=0.18 X-14.39$ & 79.93 \\
\hline EG & $Y=0.33 X-32.7$ & 98.94 \\
\hline $\mathrm{OM}$ & $Y=0.26 X-22.93$ & 88.20 \\
\hline $\mathrm{OB}$ & $Y=0.19 X-13.68$ & 72.02 \\
\hline OR & $Y=0.04 X-7.49$ & 187.18 \\
\hline UD & $Y=0.10 X-12.32$ & 123.29 \\
\hline EK & $Y=0.22 X-19.84$ & 90.20 \\
\hline \multirow[t]{2}{*}{ Mean } & $Y=0.22 X-19.82$ & 110.25 (SD 27.9) \\
\hline & Pooled regression & $\begin{array}{c}Y=0.186 X-20 \cdot 12 ; \text { if } Y=0, X \\
=108.18 \mathrm{mg} / \mathrm{kg}\end{array}$ \\
\hline
\end{tabular}

Results of individual regression analysis of $\mathrm{N}$ balance (apparent) on $\mathrm{N}$ intake are as shown in Table 5. Mean intake predicted to achieve $\mathrm{N}$-balance was $108 \cdot 18 \mathrm{mg} \mathrm{N} / \mathrm{kg}$ bodyweight per $\mathrm{d}$ with a range of $72.02-187.18 \mathrm{mg} \mathrm{N} / \mathrm{kg}$ body-weight. The mean protein requirement, including the estimated sweat and skin losses of $7.46 \mathrm{mg} \mathrm{N} / \mathrm{kg}$ body-weight, was estimated as $117.71 \mathrm{mg} \mathrm{N} / \mathrm{kg}$ body-weight per $\mathrm{d}$.

Calculations of the maintenance protein requirement were performed with the $\mathrm{N}$ balance values using the principle of the multiple-level individual responses method of Rand et al. (1979).

The mean protein requirement of the subjects was thus $110.25 \mathrm{mg} \mathrm{N} / \mathrm{kg}$ body-weight per $\mathrm{d}$ or $0.60 \mathrm{~g}$ protein $/ \mathrm{kg}$ per $\mathrm{d}$. Estimates for individual variations to cover $97.5 \%$ of the population adjusted this value to $0.75 \mathrm{~g}$ protein $/ \mathrm{kg}$ body-weight per $\mathrm{d}$. 
Table 6. Biological value (BV), net protein utilization (NPU) and true and apparent digestibilities of the diet at different levels of protein intake for Nigerian college students

(Mean values and standard deviations)

\begin{tabular}{|c|c|c|c|c|c|c|c|c|}
\hline \multirow{3}{*}{$\begin{array}{l}\text { Level of protein } \\
\text { intake }(\mathrm{g} / \mathrm{kg} \\
\text { body-wt } \\
\text { per d) }\end{array}$} & \multirow{2}{*}{\multicolumn{2}{|c|}{ BV }} & \multirow{2}{*}{\multicolumn{2}{|c|}{ NPU }} & \multicolumn{4}{|c|}{ Digestibility } \\
\hline & & & & & \multicolumn{2}{|c|}{ Apparent } & \multicolumn{2}{|l|}{ True } \\
\hline & Mean & SD & Mean & SD & Mean & SD & Mean & SD \\
\hline 0.30 & 91.77 & $11 \cdot 75$ & 90.79 & 11.04 & $66 \cdot 28$ & 8.57 & 99.42 & 8.56 \\
\hline 0.45 & $71 \cdot 47$ & 7.91 & 67.19 & $9 \cdot 16$ & $70 \cdot 17$ & 4.81 & 93.87 & 5.09 \\
\hline 0.60 & $68 \cdot 24$ & $4 \cdot 88$ & $63 \cdot 10$ & 5.58 & 74.19 & 3.31 & 92.2 & $3 \cdot 30$ \\
\hline 0.75 & $54 \cdot 63^{*}$ & 4.92 & $51.82^{*}$ & 5.14 & $80.75 \mathrm{NS}$ & 1.53 & $94.82 \mathrm{NS}$ & 1.86 \\
\hline
\end{tabular}

NS, not significant, $P>0 \cdot 05$.

* Mean values were significantly different from the other values in the column (one-way ANOVA): $P<0 \cdot 05$.

The BV, NPU and the true and apparent digestibilities for the dietary protein at the different levels of $\mathrm{N}$ intakes are summarized in Table 6. The BV and NPU were significantly reduced $(P<0.05)$ with increase in protein intake. Digestibilities (true and apparent) were not significantly affected by increasing protein intake. However, values of apparent digestibility were relatively lower at low-protein intake levels than at higher levels.

\section{DISCUSSION}

The $\mathrm{N}$ balance method was used in the present study to estimate the protein requirements of Nigerian adult males. Apart from the earlier studies made by Nicol \& Phillips (1976), the obligatory $\mathrm{N}$ loss method was used recently to estimate the protein requirement of Nigerians (Atinmo et al. 1985). The subjects who participated in the present study were young, healthy, medical students and thus provided a basis for comparison of our results with those of other studies elsewhere in the world. In particular, since none of the subjects had any disease condition that could contribute to an increased protein requirement during the whole period of the experiment, our results can be compared with those of Caucasians.

$\mathrm{N}$ balance was observed with increasing protein intake level from the submaintenance to the maintenance level. Although the criss-cross design adopted here for the feeding of the different protein levels has its advantages, it is pertinent to note that the order in which the subjects received the protein did influence their response in terms of $\mathrm{N}$ balance; moving from a higher to a lower protein level seemed to have a different effect on $\mathrm{N}$ balance than moving from a lower to a higher level of protein intake. The individual responses to the different levels of $\mathrm{N}$ intake could not strictly be defined by a straight line according to the Rand's model (Rand et al. 1979). Studies in experimental animals and man have also shown that $\mathrm{N}$ balance response is not linear throughout the entire submaintenance range (Inoue et al. 1973; Young et al. 1973). Nonetheless, the variation in the individual responses, observed in the present study, seem to underscore the fact that at lower protein intake level, adaptive mechanisms tend to occur and that such adaptive mechanisms may also be influenced by the order in which the protein levels are given.

The subjects showed a cumulative apparent positive $\mathbf{N}$ balance from intakes of about $0.60-0.70 \mathrm{~g}$ protein $/ \mathrm{kg}$ body-weight. The sum of obligatory urinary and metabolic faecal $\mathrm{N}$ losses with an appropriate allowance for sweat and integumental losses obtained in the 
recent study by Atinmo et al. (1985) was $69 \cdot 23 \mathrm{mg} \mathrm{N} / \mathrm{kg}$ body-weight. This value is much lower than that of $110.25 \mathrm{mg} \mathrm{N} / \mathrm{kg}$ body-weight per $\mathrm{d}$ obtained in the present study through regression analysis of the values for individual subjects on $\mathrm{N}$ balance. Furthermore, it is necessary to point out that the present study did not include the estimation of miscellaneous $\mathrm{N}$ losses, thus the real maintenance requirement, taking into consideration an average skin $\mathrm{N}$ loss of $7.46 \mathrm{mg} \mathrm{N} / \mathrm{kg}$ obtained from the study by Atinmo et al. (1985), would be $117.71 \mathrm{mg} \mathrm{N} / \mathrm{kg}$ per $\mathrm{d}$. This difference in estimates emphasizes the importance of using total losses of $\mathrm{N}$ in estimating requirements levels. As pointed out by Wallace (1959), error inherent in the $\mathrm{N}$ balance method could lead to an underestimation of total $\mathrm{N}$ losses and thus to an overestimation of $\mathrm{N}$ retention and underestimation of protein requirements. Based on our results and those of Atinmo et al. (1985), it seems that the obligatory $\mathrm{N}$ loss method tends to underestimate the minimum requirement for protein, if adaptive metabolic changes occur throughout the submaintenance range of protein intakes.

The present estimate of $0.69 \mathrm{~g}$ protein $/ \mathrm{kg}$ per $\mathrm{d}$ is higher than values obtained using single protein sources for Caucasians and orientals (Young et al. 1973; Huang \& Lin, 1982) but compares favourably with results from orientals receiving a mixed-vegetable diet (Huang \& Lin, 1982).

The safe level of protein or $\mathrm{N}$ intake includes an allowance for covering individual variation. This is the mean requirement plus two standard deviations which is believed to satisfy the needs of nearly all $(97.5 \%)$ the population. From our results, such a safe level of intake was estimated as $0.75 \mathrm{~g}$ protein $/ \mathrm{kg}$ body-weight. This value, even when adjusted for the quality of the protein consumed, is much higher than that of $0.57 \mathrm{~g}$ protein $/ \mathrm{kg}$ bodyweight recommended by the Joint FAO/WHO ad hoc Expert Committee on Protein Requirements, (World Health Organization, 1973) and corresponds to the value given by the most recent report of the Food and Agriculture Organization/World Health Organization/United Nations University, 1985).

Utilization of protein- $\mathrm{N}$ in the diets was high at $0.38 \mathrm{~g}$ protein $/ \mathrm{kg}$ body-weight but decreased significantly with increasing protein intake, as suggested by the BV and NPU estimates. This inferred a decreased efficiency in protein utilization as the maintenance level of protein intake was approached. These results fully support the findings of Young et al. (1973) and those of Inoue et al. (1973). Utilization of protein consumed at a level just adequate to meet requirements is, however, significantly less efficient than would be assumed from biological determinations of protein value in animals and man. This is borne out by the need to supply more protein to achieve $\mathbf{N}$ balance than factorial measurement of total obligatory $\mathrm{N}$ loss would predict (Young et al. 1973). Based on the present study, the NPU of Nigerian local diets at near maintenance levels may be estimated as the mean value of NPU at the protein intake levels of 0.6 and $0.75 \mathrm{~g} / \mathrm{kg}$, that is $57.5 \mathrm{~g} /$ $\mathrm{kg}$. This value compares favourably with that of egg protein, as given by Kishi et al. (1978) and Huang \& Lin (1982). From these findings the efficiency of dietary protein utilization at the maintenance level may be considered to be about $60 \%$ in young Nigerian men.

This research was supported in part by grants from the United Nations University, University of Ibadan Research Grants and Nigerian Institute of Social and Economic Research (NISER). The authors wish to thank Professor Nevin Scrimshaw and Professor Doris Calloway for their advice and critical evaluation of the manuscript. They thank the subjects for their invaluable co-operation in the study. 
Calloway, D. N. \& Merger, S. (1971). Journal of Nutrition 101, 205-216.

Food and Agriculture Organization/World Health Organization/United Nations University (1985). Technical Report Series, no. 724 Geneva: WHO.

Garza, C., Scrimshaw, N. S. \& Young, V. R. (1977). Journal of Nutrition 107, 335-352.

Huang, P. C. \& Lin, C. P. (1982). Journal of Nutrition 112, 897-907.

Inoue, G. \& Fujita, J. (1974). Nutrition Reports International 10, 201-207.

Inuoe, G., Fujita, J. \& Niiyuama, Y. (1973). Journal of Nutrition 103, 1673-1687.

Kishi, K., Nivatant, S. \& Inoue, G. (1978). Journal of Nutrition 108, 658-669.

Munro, H. D. \& Fleck, A. (1969). Mammalian Protein Metabolism, vol. 3, pp. 423-525. [H. D. Munro and J. B. Allison, editors]. New York: Academic Press.

Nicol, B. M. \& Phillips, P. G. (1976). British Journal of Nutrition 36, 337-348.

Oddoye, F. A. \& Margen, S (1979). Journal of Nutrition 109, 363-377.

Rand, W. M., Scrimshaw, N. S. \& Young, V. R. (1979) American Journal of Clinical Nutrition 30, $1129-1134$.

Wallace, W. M. (1959) Federation Proceedings 18, 1125-1130.

World Health Organization (1973). Techincal Report Series, no. 522. Geneva: WHO.

Young, V. R., Taylor, Y. S. M. Rand, W. M. \& Scrimshaw, N. S. (1973). Journal of Nutrition 103, $1164-1174$. 